

\section{Shirkah}

Journal of Economics and Business

Vol. 3, No. 1, January-April 2018

ISSN: 2503-4235 (p); 2503-4243 (e)

\section{Editor in Chief}

Dwi Condro Triono

\section{Managing Editor}

Jasanta Peranginangin

\section{Editorial Boards}

Abdul Azim Islahi,

Islamic Economics Institute, King Abdulaziz University, Saudi Arabia

Abu Umar Faruq Ahmad,

UBD School of Business and Economics Universiti, Brunei Darussalam

Cedomir Nestorovic,

ESSEC Business School Asia Pacific, Singapore

Fitri Wulandari,

Faculty of Islamic Economics and Business, IAIN Surakarta, Indonesia Johan Fischer,

Department of Social Sciences and Business Roskilde Universitetscenter, Denmark Muhamed Zulkhibri,

Islamic Research and Training Institute, Islamic Development Bank, Saudi Arabia M. Kabir Hassan,

Department of Economics and Finance, University of New Orleans, United States Musa Asy'arie,

Faculty of Islamic Economics and Business, IAIN Surakarta, Indonesia

Nunung Nurul Hidayah,

Aston Business School, Aston University, Birmingham, United Kingdom

Saim Kayadibi,

Department of Economics, Kulliyyah of Economics and Management Science, International Islamic University Malaysia, Malaysia 
Shaikh M Ghazanfar,

Departement of Economics, University of Idaho, Russian Federation

Sigit S. Wibowo,

Department of Management, Faculty of Economics and Business, Universitas Indonesia, Indonesia

Vihang R. Errunza,

Desmarais Global Finance Research Centre, Desautels Faculty and Management, McGill University, Canada

\section{Assistant to Editor}

M. Endy Saputro

M. Zainal Anwar

Shirkah Journal of Economics and Business is a peer-reviewed journal published three times a year (January-April, May-August and September-December) by Faculty of Islamic Economics and Business, Institut Agama Islam Negeri (IAIN) Surakarta Central Java, Indonesia. The main objective of Shirkah is to offer an academic space of exchange ideas and initiate the increase number of qualified article produced by postgraduate students, practitioners and academicians.

\section{Editorial Office}

Ruang Jurnal Shirkah

Lantai Dasar, Sayap Barat, Fakultas Ekonomi dan Bisnis Islam, IAIN Surakarta

Jln. Pandawa No. 1, Kartasura, Sukoharjo, Jawa Tengah Kode Pos. 57168

Phone (+62271) 781516 Fax: (+62271)782336

E-mail: shirkahjournal@iainsurakarta.ac.id; shirkahiainsurakarta@gmail.com

Website: http://shirkah.or.id/ 


\section{Shirkah}

Journal of Economics and Business

Vol. 3, No. 1, January-April 2018

ISSN: 2503-4235 (p); 2503-4243 (e)

\section{Table of Contents}

\section{Articles}

Aqeel Akhtar

Fahad Ahmed Qureshi

Mubeen Butt

Laws of Collateral in Today's World in Islamic Perspective

Anton Bawono

Creative Economic Development of Pesantren

Dwi Umardani

Conventional Home Loan and Islamic Home Financing in

Comparative Perspective

Iha Haryani

Dian Riskarini

Tia Ichwani

Business Development Strategy Model of SMEs

through SWOT and EFE-IFE Analysis

Ika Yoga

Halal Emotional Attachment on Repurchase Intention

Anik

Iin Emy Prastiwi

Macro Economic Challenges and Third Party Funds of Islamic Commercial Banks in Indonesia 


\title{
Halal Emotional Attachment on Repurchase Intention
}

\author{
Ika Yoga \\ Faculty of Islamic Economics and Business \\ IAIN Surakarta \\ yogezt@gmail.com
}

\begin{abstract}
This research examines the position of emotional attachment as a mediation of the influence between halal awareness, halal logos and food ingredients composition on repurchase intention of buying halal products. This research brings sample of consumers who have consumed or have purchased halal products. Due to the population is unknown, by using the Lameshow formula, a total of 384 respondents were obtained. Halal emotional attachment, as this research shows, is able to play a salient role as a mediator of the influence among three aforementioned variables on repurchase intention. This research would have been an effort to contribute marketing halal products as a new concept of the emotional attachment.
\end{abstract}

Keyword: halal, Lameshow, marketing halal, repurchase intention

\section{Introduction}

Much has been studied on repurchase interest while paying attention to the halalness of a good product, not yet those by which use a variable consisting of the inclusion of halal logos, material composition, halal awareness and halal knowledge. In fact the demand for halal products has significantly increased nowadays not because of the increasing public awareness of the implementation of faith and devotion only, but used to gain lifestyles also (Omar, 2012; Borzooei \& Asgari, 2013). Consuming halal products basically not only meets physical needs but rather meets the emotional needs of consumers where by consuming halal products, they 
have implemented one of the teachings of Islam. This is an implementation from QS. al-Maidah: 88 which provide an overview for Muslims to consume halal food and thoyib as an effort to carry out the commands of Allah. Consuming halal food for a Muslim becomes part of the worship.

Doubts on halal products have broadly implications on microeconomic conditions and macro economics of the country (Golnaz, 2012). The competition among business people is also increasing with the emergence of brand image of halal (Omar, 2012). The existence of various halal identities which are generally characterized by the halal logo on its product packaging is used as a good promotion tool to attract consumers (Ghadikolaei, 2016). An effort of emotionally attaching the "halal" of the product is one of the most effective ways to attract consumers buying their products. While someone emotionally consumes a halal product the experience would be attached; it is likely that they will consume the product again. Emotional attachment can be used as a tool to encourage consumers to continue to buy a product (Schifferstein \& Pelgrim, 2008; Fournier, 1998; Malar, 2011). Various strategies of winning market competition are carried out by means of creating halal emotional attachments to consumers (Malar, 2011). Brand image as a halal product can be used as a tool to attract consumers' attention. Creating a brand image of halal product is supported, among others, with putting the halal logo on the product bundle, inserting of halal ingredients and endorsing use of of famous Muslim artists in order to convince the consumer (Afendi, N.A., et al., 2014).

The impact of emotional attachment will more easily emerge where there will be a feeling of attachment to a particular group of people after doing an action of buying a product (Malar, 2011). Dealing with rebuying interest of halal products, the ideal self will emerge when someone uses halal products, emotionally they will feel as a part of the group, the 
Muslim group (Aziz \& Chok, 2013). Creating a strong self-ideal will have a tremendous impact on consumers' attachment to a particular brand so that it will bring loyalty to the consumers themselves (Ali, Xiaoling, Sherwani, $\&$ Ali, 2018). One characteristic of guaranteed halal in Indonesia is the halal logo issued by Majelis Ulama Indonesia (MUI) (Ab Talib, 2017). The presence of this halal logo is generally being beneficial for Muslim and non-Muslim consumers because thehalal logo shows that all processes carried out are well maintained (Norafni, 2013; Ghadikolaei, 2016).

Basically awareness is a form of effort to understand, feel and be aware of something. Aziz, \& Vui, C.N., (2013) shows that there is a positive relationship between halal awareness and intention to buy among consumers. Conversely, a research by Ghadikolaei (2016) finds that halal awareness provides a negative relationship to consumer buying interest based on its relationship with consumer attitudes. Dealing with the halal logo on the packaging of a product, Rambe \& Afifuddin (2012) demonstrate that the inclusion of a halal logo on a product's packaging has a positive influence on consumers' buying interest. In addition, Nurul and Muchlisin (2014) found that halal certification indicated by halal logos did not affect consumers' choices in consuming a product or food. Previous studies on halal food have focused on the choice of ingredients or composition of food ingredients (Al-Mazeedi, Regenstein, \& Riaz, 2013). Yunus, et all, (2013) justifies the results that the composition of food ingredients can be a determining factor and has a positive influence on consumer buying interest. Instead, diferent results shown by Hussin et al., (2013), they finds that the factor of material composition has a negative influence on consumer buying interest (see also Ahmad, Omar, Munap, \& Rose, 2018). This article is intended to locate halal emotional attachments as a form of theoretical synthesis of the previous reseach. 
In addition, according to Ajzen (2005), the most dominating variables in building the theory of planned behavior (TPB) are attitudes that encourage behavior, subjective norms and behavioral control. In this article, the concept of TPB have been applied in building the concept of consumer behavior towards their demand for consuming halal products. Norazah (2014) states that attitudes are the level of consumer perceptions of the behavior carried out that can provide benefits. This study reveals that attitudes have a positive influence on consumer preferences to create consumer buying intentions on halal products. The positive attitude of consumers is also scientifically attested (Mukhtar \& Butt, 2012) where an Islamic identity attached in a product encourages the emergence of a positive attitude of consumers to buy the product. Research on the influence of subjective norms on consumer behavior buying halal products take the same result as those explore the people's preferences that has a positive impact on increasing consumer interest to consumingthe halal one (Nisson \& Earl, 2015; Siddiqi, 1992; Baker, 2010; Hanzaee \& Lotfizadeh, 2011). Consuming halal products behavioral control has played an important role to create awareness that encourages someone to state that the products they consume are truly halal and good products (Shah \& Nazura, 2011).

Halal is any action that is in accordance with Islamic sharia. Halalness of a product becomes the main parameter when someone chooses a product (Rambe \& Afifuddin, 2012). The concept of halal would behigh appreciated for which the product are healthy, clean and tasty (Burgmann, 2007). Halal is etymologically described as something that can be done because it does not violate existing provisions (Maulana, 2008). The concept of halal has been widely applied to consumer products that are circulated in the community and have even spread to service products (Lada, 2009). A product is declared as a halal product that must at least fulfill conditions such as no substance from pork, unclean, a tool used 
free of impurity, safe for consumption, and the ingredients do not contain prohibited substances (Abd Rahman, Asrarhaghighi, Ab Rahman, 2015; Sariwati \& Nurul, 2014). This article employs such halal variables as halal logo, material composition and halal awareness. Furthermore, awareness here refers to a form of understanding, able to feel and an awareness of what is experienced and lived (Ardayanti, 2013). Halal awareness arises based on the level of Muslim understanding of the concept of halal, all the processes that follow it and makes it as a priority of consumption (Yunus, et all, 2013).

\section{Determining Hypothesis}

There are such hypothesis determined in this article, finding the relation among halal awareness, halal logos, emotional attachment and repurchase intentions as further detail. H1: There is an influence between halal awareness and emotional attachment. H2: There is an influence between halal logos and emotional attachments. H3: There is an influence between the composition of food ingredients and emotional attachments. H4: There is an influence between halal awareness and repurchase intention. $\mathrm{H} 5$ : There is an influence between halal awareness and repurchase intention. H6: There is an influence between the composition of food ingredients and repurchase interest. H7: There is an influence between Emotional Attachment and repurchase intention. H8: There is a role for halal emotional attachment as a mediation of the influence between halal awareness, halal logos and food ingredients composition with repurchase interest.

A logo states that a halal product can be used as an effort to create an islamic branding to bind customers (Berning, 2009). Tai et all (2012) states that branding is embedded in the mind of consumers which can be used to create the perception of products. In this article, the logo as 
a certification about the halalness of a product have informed that the product is truly safe and guaranteed in healthy and cleanliness process (Pepper, 2009). Halal logo can reflect a tool to show that the product really belongs to the halal product category. Halal logo can be used as an effort to create branding products (Yunus et all, 2013; Anam, Sanuri, Ismail, 2018). Consumers visually see that a halal logo on the product brings about an emotional influence of consumer attachment of the product in doing so consumers will return to using the product (Riaz \& Chaudry, 2004; Al-Mazeedi et al., 2013). Material composition is the main key that determines whether a product can be said as halal product or not (Abd Rahman et al., 2015). According to Yunus, et all (2013), the composition of materials can be used as a material consideration for consumers to choose the item or not. Material composition can show that these products are truly halal products that lead the emotional attachment of consumers to use the product returns (Al-Mazeedi et al., 2013).

Emotional attachment is an attempt to embed a product emotionally among the consumers. This can be used as a tool to create consumer loyalty to use the product again (Grisaffe \& Nguyen, 2011). Emotional attachment can build close relationships between consumers and brands of a product or service (Patwardhan \& Siva, 2013). The emotional attachment indicator used in this study is emotional interest, trust in the product and emotional attachment to the product (Pedeliento, et al, 2016). 


\section{Figure 1. Framework}

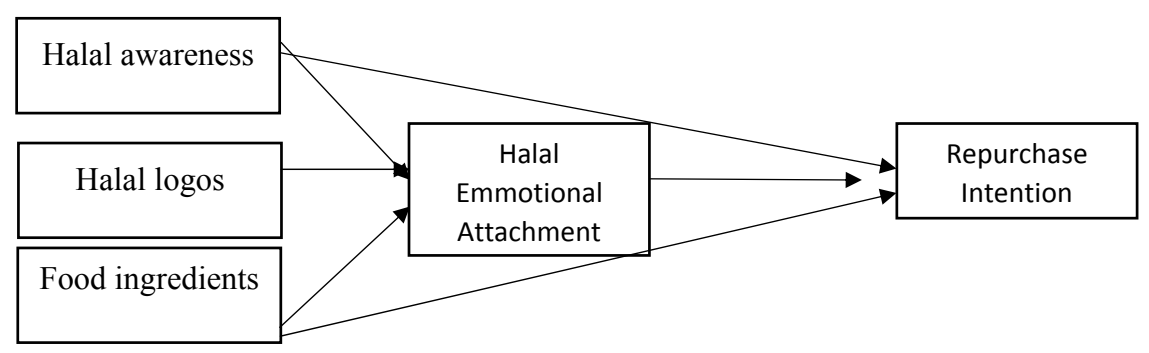

\section{Variable Operational Definition}

This article runs a population of those who have consumed halal labeled products with an unknown population by using the Lemeshow formula due to nothing found information of the population used is 384 . The sampling technique used is incidental sampling, taking sample of whoever the author met and considered meet the criteria as a research sample. The operational definition of each variable used in this study is as follows. Repurchase intention refers to the attitude of consumers to continue using the product. Indicators of interest in repurchasing halal products used in this article are: (1) consumer interest in using halal products; (2) plans to reuse halal products in the future; and (3) consumer needs to use halal products (Golnaz, 2012).

This article refers to halal awarnes which is in accordance with findings by Yunus, et all (2013) where halal awareness is the level of consumer understanding of halal products or problems of issues concerning halal. Theese indicators of halal awarness used are; (1) understanding or knowledge; (2) be aware of halal; (3) cleanliness; and (4) product safety. Halal logo can reflect as a tool to show that the product really belongs to the halal product category. Halal logo can be used as an effort to create branding products (Yunus et all, 2013; Muhamad, Leong \& Md. 
Isa, 2017). The halal logo indicator in this research consists of; (1) the importance of the brand; (2) brand familiarity; (3) consumer trust; and (4) a halal logo (Kurokawa, 2011).

The composition of food ingredients is the main key that determines whether a product can be said as halal product or not. According to Yunus, et all (2013), the composition of materials can be used as a material consideration for consumers to choose the item or not. The indicators used in this article are (1) material information; (2) foreign terms in composition; and (3) quality of food ingredients. Emotional attachment is an attempt to embed a product emotionally in the eyes of consumers(Ali et al., 2018). This can be used as a tool to create consumer loyalty to use the product again (Grisaffe \& Nguyen 2011). The emotional attachment indicator according to Pedeliento, et al (2016) that used in this article are (1) emotional interest, (2) trust in the product; (3) emotional attachment to the product.

\section{Data Analysis Method}

\section{Instrument Test}

The instrument test carried out in this article consisted of testing validity and reliability. The technique used in the validity test in this article is to do a correlation between scores of item statements with a total construct or variable score. This technique compares the calculated $r$ value with $r$ table; $r$ table is sought at the significance of 0.05 with the 2 -sided test and the amount of data $(\mathrm{n})=30, \mathrm{df}=\mathrm{n}-2$ then the $\mathrm{r}$ table is 0.3610 . The next data quality test is the reliability test performed by looking at the Croncbach Alpha Coefficien statistical value. The data is said to be reliable if the Croncbach Alpha Coefficien value is more than 0.7. 


\section{Classic Assumption Test}

The Classical Assumption Test used in this article consisted of tests of normality, multicollinearity and heteroscedasticity. Normality test aims to test if the regression model, disturbing or residual variables have normal distribution (Zulfiu, Ramadani, \& Dana, 2015). The normality test is done so that it meets as a good regression condition that is having a normal distribution. This article proposes to examine the impact of halal logo as an extrinsic food packaging cue on perceived food quality moderated by the role of consumer knowledge (Abd Rahman et al., 2015). This article indicate that the halal-labelled products create a psychological impact about the quality of the food product. The findings can be adopted by the marketers for the development of proper marketing strategies. The empirical investigations of this paper could offer the base to the marketers to invest in favorable product packaging cues (Syukur \& Nimsai, 2018). The role halal logo as a food quality indicator has previously been overlooked in the literature. The impact of halal logo on food quality perception is emergent with avenues for study across various cultures and religions (Abd Rahman et al., 2015).

There are two ways to detect if the residual is distributed or not, that is by means of graph analysis and statistical tests. Test normality using a graph may be wrong if you look carefully, because physically it may look normal but not necessarily in accordance with statistical tests. This article use the Kolmogrov-Smirnov test. The basis for decision making is if the probability of significance is above the $5 \%$ confidence level ( $\mathrm{p}$ value $\geq 5 \%$ ) then the distribution of research data is declared normal and if the $\mathrm{p}$ value is $<5 \%$ then the distribution of data is declared abnormal and does not meet the regression analysis model (Ghozali, 2016).

The next test is multicollinearity which shows a correlation between one or more independent variables and other independent variables 
(Ghozali, 2013). The value of Tolerance Value or Veriabel Inflation Factor (VIF) can be used as an indicator of whether or not muliticolinearity is a multicollinearity-free regression model that has a VIF value between 1-10 and has a tolerence factor close to one (Ghozali, 2013). The third classic assumption test is the heteroscedasticity test which aims to test whether the regression equation has residual variance inequality from one observation to another. This test is carried out by the Glejser test method which can be concluded if the significance level of more than 0.05 does not occur heteroscedasticity symptoms (Ghozali, 2016).

\section{Model Test}

Model tests consist of $\mathrm{F}$ test and determination test. According to (Ghozali, 2013), the F test was conducted to see whether all the independent variables included in the model could be used to explain the dependent variable. If $f$ count $>f$ table or level of certification $<0.05$, it can be concluded that the model is worthy of use. The next test is the deterination test where this test is essentially a tool to measure how much the ability of the model in explaining variations that occur in the dependent variable (Ghozali, 2016).

\section{Hypothesis testing}

Hypothesis testing used in this article includes two types, namely;

a. Path analysis

In this article, the analysis used to test the hypothesis that has been proposed is between the variables hypothesized using path analysis. This analysis is used to determine the level of influence on a causal relationship, which is carried out from the results of the survey (Ghozali, 2013). Path analysis is used to analyze using multiple linear regression analysis. Multiple 
linear regression is stated in the mathematical equation as follows:

$$
\begin{aligned}
& Z=a+\beta 1 X 1+\beta 2 X 2+\beta 3 X 3+e \ldots \ldots \\
& Y=a+\beta 6 X 1+\beta 7 X 2+\beta 8 X 3+\beta 9 Z+e
\end{aligned}
$$

b. Sobel test

This test is conducted to see if there is a significance of the use of mediating variables in the path analysis. According to Ghozali (2013) the formula used to calculate the standard error of indirect influence is;

$$
\mathrm{Sab}=\sqrt{ } b 2 S a 2+a 2 S b+S a 2 S b
$$

Whereas to calculate the partial indirect effect, the $t$ value of the coefficient of $\mathrm{ab}$ is calculated $\mathrm{t}=a b / S a b$, where if there is a mediating effect, the value of $t$ counts $>t$ table

\section{Characteristics of Respondents}

It can be seen the description of the size and the percentage of respondents based on gender, age and occupation of respondents. The results are as follows:

Table 1. Frequency Distribution of Respondents by Gender

\begin{tabular}{|c|l|c|c|}
\hline & Gender & Number of people & Percentage (\%) \\
\hline 1 & Male & 169 & 44,01 \\
\hline 2 & Female & 215 & 55,99 \\
\hline \multicolumn{2}{|c|}{ Amount } & 384 & 100 \\
\hline
\end{tabular}

Source: primary data is processed, 2018 
Table 2. Frequency Distribution of Respondents by Age

\begin{tabular}{|c|l|c|c|}
\hline & \multicolumn{1}{|c|}{ Age Range } & Number of people & Percentage (\%) \\
\hline 1 & $<25$ years & 86 & 22,40 \\
\hline 2 & $26-35$ years & 183 & 47,66 \\
\hline 3 & $36-45$ years & 115 & 29,94 \\
\hline \multicolumn{2}{|c|}{ Amount } & 384 & 100 \\
\hline
\end{tabular}

Source: primary data is processed, 2018

Table 3. Frequency Distribution of Respondents by Work

\begin{tabular}{|c|l|c|c|}
\hline & \multicolumn{1}{|c|}{ Type of work } & Number of people & Percentage (\%) \\
\hline 1 & Housewife & 185 & 48,17 \\
\hline 2 & Employees & 104 & 27,08 \\
\hline 3 & Private & 95 & 24.75 \\
\hline \multicolumn{2}{|c|}{ Jumlah } & 384 & 100 \\
\hline
\end{tabular}

Source: primary data is processed, 2018

\section{Results of Data Analysis}

Validity test

Testing the validity test was conducted on five variables by using an initial sample of 30 samples. The technique used is to do a correlation between scores of item statements with a total construct or variable score. This technique compares the value of $r$ count with $r$ table, $r$ table is sought at the significance of 0.05 by the 2-sided test and the number of data ( $\mathrm{n}$ ) $=30, \mathrm{df}=\mathrm{n}-2$ then the $\mathrm{r}$ table is 0.3610 . It has been concluded that all questions used for the variable halal awareness are valid to be used as a research questionnaire because it has a Pearson Correlation value for each item of 0.778 for question $1,0.787$ for question 2, 0.829 for question 3, 
and 0.585 for question 4 which is greater than the $r$ table value of 0.3610 . This is strengthened by the results of the significance for each question item less than the level of significance used in this study that is 0.05 . For the halal logo variable, by looking at the results of the validity test calculation, it can be concluded that all question items used to represent the halal logo variable are valid to be used in this study because they have Pearson Correlation values for questions 1, 2, 3, 4 and 5 more large of the $r$ table value is 0.3610 , this was also strengthened by the results of a significance test of less than 0.05 .

Validity test results for food ingredient composition variables, when looking from the results of the calculations performed, the Pearson Correlation value produced is 0.938 for question item $1,0.935$ for item 2, 0.938 for question item 3 and 0.925 for question item 4 . It can be concluded that the question item is valid to use because it has a Pearson Correlation value greater than $\mathrm{r}$ table of 0.3610 and the significance level is less than 0.05 . For emotional attachment variables, avidity test results also show that all question items that represent emotional attachment variables are valid to use because they have a Pearson Correlation value greater than $r$ table of 0.3610 and a significance level of less than 0.05 . The fifth variable that is tested for validity is the variable repurchase intention. By looking at the results of the validity test of the repurchase intention variable presented in the table above it can be concluded that all valid question items are used for research because it has a Pearson Correlation value of more than $r$ table value of 0.3610 and a significance level of less than 0.05 .

\section{Reliability Test}

The next data quality test is the reliability test which is done by looking at the Croncbach Alpha Coefficient statistic value. The test results conducted in this article are presented in the table below 
Table 4. Reliability Test

\begin{tabular}{|l|c|c|c|}
\hline \multicolumn{1}{|c|}{ Variable } & $\begin{array}{c}\text { Cronbach's } \\
\text { Alpha }\end{array}$ & Critical value & Conclusion \\
\hline Repurchase Intention & 0,964 & 0,70 & Reliable \\
\hline Emotional Attachment & 0,942 & 0,70 & Reliable \\
\hline Halal awareness & 0,871 & 0,70 & Reliable \\
\hline Halal logo & 0,950 & 0,70 & Reliable \\
\hline Food ingredients & 0,950 & 0,70 & Reliable \\
\hline
\end{tabular}

Source; Primary data is processed, 2018

According to Ghozali (2013) the Cronbach's Alpha number> 0.70 shows that the variables are reliable and feasible to use as research variables. From the figures presented in the table above shows that the variables used in this study can be stated as reliable which means that each respondent provides a consistent answer to be used as a tool to measure variables.

\section{Classic Assumption Test}

Normality Test

The existence of intruder or residual variable which is not normally distributed in the regression model can cause bias in decision making. The Kolmogorov-Smirnov test is the normality test used in this study and the results of the SPSS test will be compared with the Sig. (2-tailed) value with $\alpha=0.05$ so that it gives results as presented in the table below: 
Table 5. Normality Test

\begin{tabular}{|ll|r|r|r|r|r|}
\hline & & \multicolumn{1}{c|}{ KH } & \multicolumn{1}{c|}{ LH } & \multicolumn{1}{c|}{ KB } & \multicolumn{1}{c|}{ EA } & \multicolumn{1}{c|}{ MBU } \\
\hline $\mathrm{N}$ & 384 & 384 & 384 & 384 & 384 \\
Normal & Mean & 20.8203 & 24.7083 & 20.1719 & 15.1380 & 11.7630 \\
Parameters $^{\mathrm{a}}$ & Std. Deviation & 1.98992 & 3.00449 & 6.53783 & 4.48662 & 2.74287 \\
Most Extreme & Absolute & .183 & .219 & .248 & .201 & .279 \\
Differences & Positive & .183 & .219 & .181 & .137 & .207 \\
& Negative & -.132 & -.216 & -.248 & -.201 & -.279 \\
Kolmogorov-Smirnov Z & 3.593 & 4.294 & 4.862 & 3.944 & 5.472 \\
Asymp. Sig. (2-tailed) & .000 & .000 & .000 & .000 & .000 \\
\hline
\end{tabular}

Test distribution is normal.

Source: primary data is processed, 2018

When viewed from the test results listed in the table above shows the results that Asymp. Sig obtained value $<0.05$ so it can be concluded that the data used in this article is normally distributed.

\section{Multicollinearity Test}

The correlation between independent variables in the regression model can lead to bias in decision making. To see this, the multicollinearity test was conducted in this article (Ghozali, 2013). Tolerance values greater than 0.1 or Variance Inflation Factor (VIF) values smaller than 10 can indicate that the data used in the study is free from multicollinearity. The following in the table below is presented the results of the multicollinearity test conducted in the article. 
Table 6. Multicollinearity Test

\begin{tabular}{|l|l|l|l|}
\hline \multicolumn{1}{|c|}{ Variable } & \multicolumn{1}{|c|}{ Tolerance } & VIF & \multicolumn{1}{c|}{ Conclusion } \\
\hline Halal awareness & 0,981 & 1,019 & $\begin{array}{l}\text { There is no } \\
\text { multicollinearity }\end{array}$ \\
\hline Halal logo & 0,982 & 1,013 & $\begin{array}{l}\text { There is no } \\
\text { multicollinearity }\end{array}$ \\
\hline Food ingredients & 0,688 & 1,453 & $\begin{array}{l}\text { There is no } \\
\text { multicollinearity }\end{array}$ \\
\hline Emotional Attachment & 0,693 & 1,443 & $\begin{array}{l}\text { There is no } \\
\text { multicollinearity }\end{array}$ \\
\hline
\end{tabular}

Source: primary data is processed, 2018

The tolerance value obtained from the results of the multicollinearity test performed as shown in the table above shows that the tolerance value for each independent variable is halal awareness (0.981), halal logo (0.982), material composition (0.688) and emotional attachment (0.693) so it can be concluded that the three independent variables in this regression model did not occur multicollinearity symptoms because the tolerance value> 0.1 .

\section{Heteroscedasticity Test}

To test whether in the regression model there is a variance inequality from the residuals, in this study heteroscedasticity test was conducted. Based on the results of the heteroscedasticity test performed by the gletzer test results are obtained as presented in the table below: 
Table 7. Heteroscedasticity Test

\begin{tabular}{|l|l|l|}
\hline \multicolumn{1}{|c|}{ Variable } & \multicolumn{1}{c|}{ Sig } & \multicolumn{1}{c|}{ Conclusion } \\
\hline Halal awareness & 0,529 & There is no heteroscedasticity \\
\hline Halal logo & 0,191 & There is no heteroscedasticity \\
\hline Food ingredients & 0,119 & There is no heteroscedasticity \\
\hline Emotional Attachment & 0,689 & There is no heteroscedasticity \\
\hline
\end{tabular}

Source: primary data is processed, 2018

Heteroscedasticity test results using the glejser test from the table above shows the variable sig value of halal awareness, halal logo, food ingredient composition and emotional attachment respectively 0.529 ; $0.191 ; 0,119 ; 0.689$ which means that all sig values> 0.05 it can be concluded that in this study there was no heteroscedasticity problem.

\section{Regression Analysis Model 1}

Regression test results for model 1, which is done, get results as listed in table below

Table 8. Regreeeion Analysis Model 1

\begin{tabular}{|c|c|c|c|c|c|}
\hline \multirow[t]{2}{*}{ Model } & \multicolumn{2}{|c|}{$\begin{array}{c}\text { Unstandardized } \\
\text { Coefficients } \\
\end{array}$} & \multirow{2}{*}{$\begin{array}{c}\begin{array}{c}\text { Standardized } \\
\text { Coefficients }\end{array} \\
\text { Beta }\end{array}$} & \multirow[t]{2}{*}{$\mathrm{T}$} & \multirow[t]{2}{*}{ Sig. } \\
\hline & B & $\begin{array}{l}\text { Std. } \\
\text { Error }\end{array}$ & & & \\
\hline (Constant) & 3.127 & .823 & & 3.801 & .063 \\
\hline Halal awareness & .050 & .130 & .017 & 3.387 & .003 \\
\hline Halal logo & .077 & .107 & .031 & 2.723 & .000 \\
\hline Food ingredients & .508 & .039 & .555 & 12.950 & .000 \\
\hline
\end{tabular}

Source: primary data is processed, 2018 
Emotional attachment $=3,127+0,050$ halal awareness $+0,77$ halal logo $+0,508$ food ingredients $+\mathrm{e}$

Based on each coefficient value in the multiple linear regression equation, it can be interpreted as follows:

1.A constant of 3.127 indicates that if the variable value of halal consciousness, halal logo and composition of food ingredients are considered constant then the emotional attachment value is 3.127 .

2. The variable coefficient of halal awareness is 0.050 , meaning that if there is an increase in the value of halal awareness by 1 point, the value of the emotional attachment variable increases by 0.050 points.

3. The halal logo variable coefficient is 0.077 , meaning that if there is an increase in the halal logo variable by 1 point, the value of the emotional attachment variable increases by 0.077 points.

4. The coefficient of food ingredients is 0.508 . With this value indicates that if there is an increase in the variable composition of food by 1 point, the value of emotional attachment increases by 0.508 .

\section{Model 1 Accuracy Test}

Based on the $\mathrm{F}$ test, the results are given as listed in the table below

Table 9. F Test Model 1

\begin{tabular}{|l|l|r|r|r|r|r|}
\hline \multicolumn{2}{|l|}{} & \multicolumn{1}{|c|}{$\begin{array}{c}\text { Sum of } \\
\text { Squares }\end{array}$} & df & $\begin{array}{c}\text { Mean } \\
\text { Square }\end{array}$ & F & Sig. \\
\hline 1 & Regression & 263.057 & 3 & 87.686 & 56.135 & $.000^{\mathrm{a}}$ \\
& Residual & 593.575 & 380 & 1.562 & & \\
& Total & 856.632 & 383 & & & \\
\hline
\end{tabular}

Source: primary data is processed, 2018

Based on the test results presented in the table above shows that the value of $\mathrm{F}$ count $>\mathrm{F}$ table and level of significance $<0.05$ so it can 
be concluded that the regression model is feasible to be used in this study. Whereas based on the determination test, it was obtained the $\mathrm{R}$ Square value of 0.307 . This value shows that the variables included in the model are able to explain the variation of the dependent variable, namely Emotional Attachment of 0.307 or $30.7 \%$.

\section{Regression Analysis Model 2}

The results of the model 2 regression test conducted in this study are presented in the table below:

Table 10. Regression Analysis Model 2

\begin{tabular}{|c|c|c|c|c|c|c|}
\hline & \multirow{2}{*}{ Model } & \multicolumn{2}{|c|}{$\begin{array}{l}\text { Unstandardized } \\
\text { Coefficients }\end{array}$} & $\begin{array}{c}\text { Standardized } \\
\text { Coefficients }\end{array}$ & \multirow{2}{*}{$\mathrm{t}$} & \multirow{2}{*}{ Sig. } \\
\hline & & B & Std. Error & Beta & & \\
\hline \multirow[t]{5}{*}{1} & \multirow{5}{*}{$\begin{array}{l}\text { Constant) } \\
\text { Halal awareness } \\
\text { Halal logo } \\
\text { Food ingredients } \\
\text { Emotional Attachment }\end{array}$} & .515 & .306 & & -.008 & .994 \\
\hline & & .632 & .096 & .030 & 2.604 & .004 \\
\hline & & 287 & .123 & .060 & 2.004 & .000 \\
\hline & & .186 & .086 & .592 & 2.138 & .000 \\
\hline & & .500 & .241 & .542 & 3.127 & .000 \\
\hline
\end{tabular}

Source: primary data is processed, 2018

Repurchase intention $=$

$0,515+0,632$ Halal awareness $+0,287$ Halal Logos + 0,186 Food ingredients + 0,500 Emotional Attachment $+\mathrm{e}$

Based on each coefficient value in the multiple linear regression equation, it can be interpreted as follows:

a) Constants of 0.515 indicate that if the variable value of halal awareness, halal logo, food ingredients composition and emotional attachment are considered constant then the value of repurchase intention is 0.515 . 
b) The variable coefficient of halal awareness is 0.632 , meaning that if there is an increase in the value of halal awareness by 1 point, the value of repurchase intention will increase by 0.632 .

c) The halal logo variable coefficient is 0.287 , meaning that if there is an increase in the halal logo value of 1 point, the value of the repurchase intention variable will increase by 0.287 .

d) Food ingredient composition coefficient is 0.186 , meaning that if there is an increase in material composition value of 1 point, it will increase the value of repurchase intention variable by 0.186 .

e) Emotional attachment coefficient of 0.500 means that if there is an increase in emotional attachment value of 1 point, it will increase the value of repurchase intention variable by 0.500 .

\section{Model 2 Accuracy Test}

Based on the $\mathrm{F}$ test, the results are given as listed in the table below

Table 11. F Test Model 2

\begin{tabular}{|l|r|r|r|r|r|}
\hline Model & \multicolumn{1}{|c|}{$\begin{array}{c}\text { Sum of } \\
\text { Squares }\end{array}$} & df & \multicolumn{1}{c|}{$\begin{array}{c}\text { Mean } \\
\text { Square }\end{array}$} & F & Sig. \\
\hline Regression & 263.057 & 3 & 87.686 & 56.135 & $.000^{\mathrm{a}}$ \\
Residual & 593.575 & 380 & 1.562 & & \\
Total & 856.632 & 383 & & & \\
\hline
\end{tabular}

Source: primary data is processed, 2018

Based on the test results presented in the table above shows that the value of $\mathrm{F}$ count $>\mathrm{F}$ table and level of significance $<0.05$ so it can be concluded that the regression model is feasible to be used in this article. Whereas based on the determination test performed, it is obtained the $\mathrm{R}$ 
Square value of 0.20 . This value indicates that the variables included in the model are able to explain the variation of the dependent variable, namely Emotional Attachment of 0.20 or $20 \%$.

\section{Path Analysis}

The amount of influence of each variable can be seen in the beta coefficient of regression model 1 and model 2 , while the value of $\mathrm{e}_{1}=$ $\sqrt{(1-0,307)}=0,832$ and the value of $e_{2}=\sqrt{(1-0,20)}=0,832=$ 0,894 . So that based on the calculation of the beta value in models 1 and 2, the calculations can be used to make the Path Diagram as follows: sub structure 1 ). emotional attachment $=0.350$ halal awareness +0.077 halal logo +0.508 food ingredients +0.832 ; sub-structure 2 ): repurchase interest $=0.832$ halal awareness +0.287 halal $\operatorname{logo}+0.186$ food ingredients +0.500 emotional attachment +0.894 .

According to Ghozali (2016), to examine the indirect effect of the independent variable on the dependent variable through intervening variables can be done by the Sobel test.

The influence of the variable halal awareness on repurchase intention through emotional attachment

$$
\begin{aligned}
& \text { Sp2p3 }=\sqrt{p 3^{2} S p 2^{2}+p 2^{2} S p 3^{2}+S p 2^{2} S p 3^{2}} \\
& \text { Sp2p3 }=\sqrt{(0,500)^{2}(0,130)^{2}+(0,050)^{2}(0,241)^{2}+(0,130)^{2}(0,241)^{2}} \\
& \text { Sp2p3 }=0,0095
\end{aligned}
$$

Based on the results of this Sp2p3 we can calculate the $t$ mediation influence statistics with the following formula:

$$
\mathrm{t}=\frac{p 2 p 3}{S p 2 p 3}=\frac{0,025}{0,0095}=2,632
$$


Based on the results of the $t$ count it can be concluded that there is an influence of halal awareness on repurchase interest through emotional attachment as a mediating variable because the value of $\mathrm{t}$ count is $2.632>$ t table 1.966161 with a significance level of 0.05 .

The influence of the halal logo variable on repurchase interest through emotional attachment

$$
\begin{aligned}
& \text { Sp2p3 }=\sqrt{p 3^{2} S p 2^{2}+p 2^{2} S p 3^{2}+S p 2^{2} S p 3^{2}} \\
& \text { Sp2p3 }=\sqrt{(0,500)^{2}(0,107)^{2}+(0,077)^{2}(0,241)^{2}+(0,107)^{2}(0,241)^{2}} \\
& \text { Sp2p3 }=0,0067
\end{aligned}
$$

Based on the results of this $\mathrm{Sp} 2 \mathrm{p} 3$ we can calculate the t statistics of mediation effects with the following formula

$$
\mathrm{t}=\frac{p 2 p 3}{S p 2 p 3}=\frac{0,0385}{0,0067}=5,7462
$$

Based on the results of the $t$ count it can be concluded that there is an influence of the halal logo on repurchase interest through emotional attachment as a mediating variable because the value of $t$ counts 5.7462> t table 1.966161 with a significance level of 0.05 .

The effect of material composition variables on repurchase interest through emotional attachments

$$
\begin{aligned}
& \text { Sp2p3 }=\sqrt{p 3^{2} S p 2^{2}+p 2^{2} S p 3^{2}+S p 2^{2} S p 3^{2}} \\
& \text { Sp2p3 }=\sqrt{(0,500)^{2}(0,039)^{2}+(0,508)^{2}(0,241)^{2}+(0,039)^{2}(0,241)^{2}} \\
& \text { Sp2p3 }=0,016
\end{aligned}
$$

Based on the results of this $S \mathrm{p} 2 \mathrm{p} 3$ we can calculate the t statistics of mediation effects with the following formula 


$$
\mathrm{t}=\frac{p 2 p 3}{S p 2 p 3}=\frac{0,254}{0,016}=15,875
$$

Based on the results of the $t$ count it can be concluded that there is an effect of the composition of the material on repurchase interest through emotional attachment as a mediating variable because the value of $t$ count is $15.875>\mathrm{t}$ table 1.966161 with a significance level of 0.05 .

\section{Discussing the Influence}

Repurchase interest in a product in this research devoted to halal products can be influenced by many factors. In this study, the authors considered that it could influence the halal awareness, halal logos and food ingredients composition and the presence of emotional attachment as variable mediated in relation to repurchase interest. Halal awareness is known based on understanding whether a Muslim is halal, knowing the proper slaughter process, and prioritizing halal food for their consumption (Yunus, et all, 2013). In this case with the awareness that the product consumed is halal product, there will be an emotional attachment to use the product again (Almossawi, 2014). Buying interest is influenced by halal awareness (Battour, Ismail, \& Battor, 2010). This is in accordance with the results obtained in this study which said that the existence of halal awareness will increase the interest in buying a product including the interest in repurchasing the halal products they consume (Berning, 2009).

Halal logo can reflect as a tool to show that the product really belongs to the halal product category. Halal logo can be used as an effort to create Branding Products (Yunus, et all, 2013). Visually consumers see that a halal logo in the product packaging can cause an emotional influence so that it can bring a feeling of consumer attachment to the product so that consumers will return to using the product (Amin, 2017). Halal logo is a 
form or way to do Islamic branding to prove that the product is truly halal product (Aziz \& Chok, 2013; Burki, 2011). Buying interest is influenced by Islamic branding (Aziz and Vui, 2013) including re-buying interest so that the results are sub-set according to the results of this study which states that halal logos affect repurchase interest.

According to Yunus, et all (2013), the composition of food ingredients can be used as a consideration for consumers to choose the item or not. The indicator used in this study is material information, foreign terms in composition, and material quality. Material composition can show that these products are truly halal products so that the emotional attachment of consumers to use the product returns (Riaz \& Chaudry, 2004). The composition of food ingredients is a tool to show consumers that these products are truly halal products so that with the composition of ingredients that are usually listed in the product packaging will increase interest in buying including repurchase interest in the halal products consumed (Abd Rahman et al., 2015).

Emotional attachment can build a close relationship between consumers and brands of a product or service (Patwardhan \& Balasubramanian, 2013). Creating emotional attachments is a tool to increase the level of sales and consumer confidence. This is consistent with what was obtained in this study where emotional attachments can increase buying interest, including repurchase interest. Emotional Attachment is an attempt to embed a product emotionally in the eyes of consumers (AlSalim, 2009). This can be used as a tool to create consumer loyalty to use the product again (Grisaffe \& Nguyen, 2011). The Emotional Attachment indicator used in this study is emotional interest, trust in the product, emotional attachment to the product (Pedeliento, et al, 2016). Referring to the indicator that there is halal awareness, halal logos and halal material composition will create consumer confidence in the product and will cause 
it to cause emotional attachment to the product and will impact on the consumer's buying interest for the first product and repurchase interest in further products.

\section{Conclusion}

The Emotional Attachment indicator used in this study is emotional interest, trust in the product, emotional attachment to the product. Referring to these indicators the existence of halal awareness, halal logos and food ingredients composition will create consumer confidence in the product and will cause it to cause emotional attachment to the product and will impact on the consumer's buying interest for the first product and repurchase interest in the product the next product. The results of this study also showed that the significant influence between the variables of halal awareness, halal logos and food composition on emotional attachments and significant influences also occurred between emotional attachment and repurchase intention. These results indicate that all hypotheses can be accepted and empirically proven in this study. 


\section{References}

Ab Talib, M. S. (2017). Motivations and benefits of halal food safety certification. Journal of Islamic Marketing, 8(4), 605-624. https://doi. org/10.1108/JIMA-08-2015-0063

Abd Rahman, A., Asrarhaghighi, E., \& Ab Rahman, S. (2015). Consumers and halal cosmetic products: Knowledge, religiosity, attitude and intention. Journal of Islamic Marketing, 6(1), 148-163. https://doi. org/10.1108/JIMA-09-2013-0068

Afendi, N.A., et al. (2014). Determinants of Halal Purchase Intention: Case in Perlis. International Journal of Business and Social Research (IJBSR), 4(5).

Ahmad, S. N. B., Omar, A., Munap, R., \& Rose, R. M. (2018). Influence of consumers' perceived brand innovativeness on customer-brand identification and brand loyalty. International Journal of Supply Chain Management, 7(4), 145-150.

Ajzen, I. (2005). Attitudes, personality and behavior (2nd ed.). UK: Open University Press.

Ali, A., Xiaoling, G., Sherwani, M., \& Ali, A. (2018). Antecedents of consumers' Halal brand purchase intention: an integrated approach. Management Decision, 56(4), 715-735. https://doi.org/10.1108/ MD-11-2016-0785

Al-Mazeedi, H. M., Regenstein, J. M., \& Riaz, M. N. (2013). The issue of undeclared ingredients in halal and kosher food production: A focus on processing aids. Comprehensive Reviews in Food Science and Food Safety, 12(2), 228-233. https://doi.org/10.1111/1541-4337.12002

Almossawi, M. M. (2014). Impact of religion on the effectiveness of the promotional aspect of product packages in muslim countries. Asia Pacific Journal of Marketing and Logistics, 26(5), 687-706. https://doi. org/10.1108/APJML-11-2013-0137

Al-Salim, F. H. (2009). Islamic Financial Product Innovation. International Journal of Islamic and Middle Eastern Finance and Management. 
Amin, H. (2017). Consumer behaviour of Islamic home financing: Investigating its determinants from the theory of Islamic consumer behaviour. Humanomics, 33(4), 517-548. https://doi. org/10.1108/H-12-2016-0102

Anam, J., Sany Sanuri, B. M. M., \& Ismail, B. L. O. (2018). Conceptualizing the relation between halal logo, perceived product quality and the role of consumer knowledge. Journal of Islamic Marketing, 9(4), 727-746. https://doi.org/10.1108/JIMA-02-2017-0019

Ardayanti, A., et, all. (2013). A Study on Halal Food Awareness Among Muslim Customers in Klang Valley. Presented at the 4th International Conference on Business and Economic Research, Bandung, Indonesia, paper 1073 .

Aziz, A. Y., \& Vui, C.N. (2013). The role of Halal awareness and Halal certification in influencing non-Muslim's purchasing intention. In Proceeding, 1819-1830.

Aziz, Y. A., \& Chok, N. V. (2013). The Role of Halal Awareness, Halal Certification, and Marketing Components in Determining Halal Purchase Intention Among Non-Muslims in Malaysia: A Structural Equation Modeling Approach. Journal of International Food and Agribusiness Marketing, 25(1), 1-23. https://doi.org/10.1080/08974 438.2013.723997

Baker, A. . (2010). Islamic branding: A conceptualization of related terms. Journal of Brand Management, 18(1), 34-49.

Battour, M. M., Ismail, M. N., \& Battor, M. (2010). Toward a halal tourism market. Tourism Analysis, 15(4), 461-470. https://doi.org/10 .3727/108354210X12864727453304

Berning, U. (2009). The market reacts to halal-compliant products: The growing marketing area for the meat products industry develops a new lifestyle. Fleischwirtschaft, 89(8), 51.

Borzooei, M., \& Asgari, M. (2013). The Halal brand personality and its effect on purchase intention. Interdisciplinary Journal OfContemporary Research In Business, 5(3). 
Burgmann, T. (2007). Halal Flexes Its Marketing Muscle, retrieved from http://www.thestar.com/business/srticle/238551.

Burki, S. K. (2011). Haram or Halal? Islamists' use of suicide Attacks as "Jihad." Terrorism and Political Violence, 23(4), 582-601. https://doi. org/10.1080/09546553.2011.578185

Fournier, S. (1998). Consumers and Their Brands: Developing Relationship Theory in Consumer Research (Vol. 24). Journal of Consumer Research.

Ghadikolaei, F. . (2016). The Effect of Halal Signs and Symptoms on Consumers' Purchase Intention in Muslim and Non-Muslim Countries- A Review. International Journal of Business and Management Invention, 5(7), 44-49.

Ghozali, I. (2013). Aplikasi analisis multivariate dengan program ibmspss 21. Semarang: Badan Penerbit Universitas Diponegoro.

Ghozali, I. (2016). Aplikasi analisis multivariete dengan program IBM SPSS 23 (8th ed.). Semarang: Badan Penerbit Universitas Diponegoro.

Golnaz, R., et, al. (2012). Assessment of Consumers' Confidence on Halal Labelled Manufactured Food in Malaysia. Social, Science. \& Humanities, 20(1), 33-42.

Grisaffe, D. B., \& Nguyen, H. . (2011). Antecedents of emotional attachment to brands. Journal of Business Research 64 (2011), 1052 1059.

Hanzaee, K. H., \& Lotfizadeh, F. (2011). Influence of family structure on consumer decisionmaking style in Iran. , 6(11), 297-304. International Journal of Business and Management Invention, 6(11), 297-304.

Hussin, S. R. (2013). Relationship between Product Factors, Advertising, and Purchase Intention of Halal Cosmetic. Pertanika J. Soc. Sci. \& Hum. 21 (S): 85 - 100 ISSN: 0128-7702.

Kurokawa, K. (2011). Challenge of the Halal food certificate for food marketing: Implications from the local branding strategy of Thailand. Studies in Regional Science, 41(4), 1045-1054. https://doi. 
org/10.2457/srs.41.1045

Lada, S., et all. (2009). Predicting intention to choose halal products using theory of reasoned action. International Journal Islamic and Middle Eastern Finance and Management, 12(1), 66-76.

Malar, L., et all. (2011). Emotional Brand Attachment and Brand Personality: The Relative Importance of the Actual and the Ideal Self. Journal of Marketing, 75, 35-52.

Maulana, A. (2008). Kamus Ilmiah Populer: Lengkap dengan EYD dan Pembentukan Istilah serta Akronim Bahasa Indonesia. Yogyakarta: Absolut.

Muhamad, N., Leong, V. S., \& Md Isa, N. (2017). Does the country of origin of a halal logo matter? The case of packaged food purchases. Review of International Business and Strategy, 27(4), 484-500. https:// doi.org/10.1108/RIBS-06-2017-0049

Mukhtar, A., \& Butt, M. M. (2012). Intention to choose Halal products: The role of religiosity. Journal of Islamic Marketing, 3(2), 108-120. https://doi.org/10.1108/17590831211232519

Nisson, C., \& Earl, A., et, all. (2015). The Theories of Reasoned Action and Planned Behavior: Examining the Reasoned Action Approach to Prediction and Change of Health Behaviors. The Wiley Encyclopedia of Health Psychology.

Norafni, F. R., et all. (2013). Awareness and Perception of Muslim Consumers on Non-Food Halal Product. Journal of Social and Development Sciences, 4(10), 478-387.

Norazah, M. . (2014). "Does celebrity credibility influence muslim and non-muslim consumers attitudes toward brands and purchase intention?" Journal of Islamic Marketing, 5(2), 227-240.

Omar, K. . et al. (2012). The Direct Effects of Halal Product Actual Purchase Antecedents among the International Muslim Consumers. American Journal of Economics June, 87-92. 
Patwardhan, H., \& Siva, K. (2013). Reflections on emotional attachment to brands: Brand romance and brand love. Journal Of Customers Behaviour, 12(1), 73-79.

Pedeliento, et al, G. (2016). Brand and product attachment in an industrial context: The effects on brand loyalty. Industrial Marketing Management, 53, 194-206.

Rambe, Y., \& Afifuddin, S. (2012). Pengaruh Pencantuman Label Halal Pada Kemasan Mie Instan Terhadap Minat Beli Masyarakat Muslim (Studi Kasus Pada Mahasiswa Universitas Al-Washliyah, Medan). Jurnal Ekonomi Dan Keuangan, 1(1).

Riaz, M. N., \& Chaudry, M. M. (2004). The value of Halal food production. INFORM - International News on Fats, Oils and Related Materials, 15(11), 698-700.

Sariwati, M., S., \& Nurul, A. . (2014). Halal Certification on Chocolate Product: A Case Study. Procedia - Social and Behavioral Sciences 121, $104-112$.

Schifferstein, H. ., \& Pelgrim, E. . (2008). Consumer-Product Attachment: Measurement and Design Implications. International Journal of Design, 2(3).

Shah, A., S., \& Nazura, M. . (2011). Applying the theory of planned behavior (TPB) in halal food purchasing. International Journal of Commerce and Management, 21(1), 8-20.

Siddiqi, M. . (1992). Islamic Consumer Behavior. In Sayyid Tahir. In Readings in microeconomics: An islamic perspective (pp. 49-60). Malaysia: Longman.

Syukur, M., \& Nimsai, S. (2018). Factors influencing the purchase intention of halal packaged food in Thailand. International Journal of Supply Chain Management, 7(4), 1-6.

Tai, et all. (2012). Brand Management. Jakarta: Indeks. 
Yunus, et all. (2013). Muslim's Purchase Intention towards Non-Muslim's Halal Packaged Food Manufacturer 145 - 154. Procedia - Social and Behavioral Sciences 130, 145-154.

Zulfiu, V., Ramadani, V., \& Dana, L.-P. (2015). Muslim entrepreneurs in secular Turkey: Distributors as a source of innovation in a supply chain. International Journal of Entrepreneurship and Small Business, 26(1), 78-95. https://doi.org/10.1504/IJESB.2015.071321

Vol. 3 No. 1, January - April 2018 
$126 \quad$ Ika Yoga

Vol. 3 No. 1, January - April 2018 


\section{Shirkah Author Guidelines}

Shirkah currently offers two routes to submit manuscripts. We highly recommend to submit the articles which are made using OJS (Open Journal System). Feel free register as author soon through visiting http:// shirkah.or.id/index.php/home/user/register. The authors may directly send their manuscripts, along with their resume, to shirkahiainsurakarta@ gmail.com. Please prepare your manuscripts, using following guidelines:

1. Manuscript must be written in English. Submitted articles should not have been published or be under review for publication with another journal.

2. Manuscript's length is about $15-20$ pages, typed in one-half spaced on A4-paper size.

3. Manuscript must include an $150-200$ word abstract and keywords.

4. Manuscript must be arranged as follows: Title, Name of Author, E-mail address, Abstract, Keywords, Introduction (including method if any), Discussion, Conclusion, References.

5. Manuscript's titles not more than ten words.

6. Manuscript must be submitted in Microsoft Word or RTF.

7. Arabic words should be transliterated according to the style of International Journal of Middle Eastern Studies.

8. Manuscript references are preferably derived from the up-to-date references.

9. The author's resume should be submitted separately, consisting of at least full name, institutional address, phone number, areas of studies, and recent publications (if any).

10. Shirkab use APA Style 6th edition (2010) as reference format writing. We suggest the use of a reference manager software such as Mendeley, Zotero, and Endnote at templating the citation style. APA Style to be used is as follows: 


\section{Book with single author}

Swann, G. M. Peter. (2014). The Economics of Innovation an Introduction. Cheltenhum \& Northampton: Edward Elgar.

in-text citation: (Swann, 2014)

\section{Articles in reference books}

Alatas, S. F. (2006). Islam and the Science of Economics in Abu Rabi', I.M. The Blackwell Companion to Contemporary Islamic Thought. USA: Willey-Blackwell (pp. 587-606).

in text citation: (Alatas, 2006)

\section{E-Book}

Hackett, Rosalind (2007). "Religous Dimentions of War and Peace: Introduction.” Dalam Gerrie ter Haar dan Yoshio Tsuruoka (Ed.), Religion and Society: An Agenda for the 21st Century (h. 3-6). Retrieved from http:// brill.nl.

in text citation: (Hackett, 2006)

\section{Master's thesis, from a commercial database}

McNieI, D. S. (2006). Meaning through narrative: A personal narrative discussing growing up with an alcoholic mother (Master's thesis). Available from ProQuest Dissertations and Theses database. (UMI No. 1434728)

in text citation: (Mc Niel, 2006)

\section{Doctoral dissertation, from an institutional database}

Adams, R. J. (1973). Building a foundation for evaluation of instruction in higher education and continuing education (Doctoral dissertation). Retrieved from http://www.ohiolink.edu/etd/

in text citation: (Adams, 1973) 


\section{Doctoral dissertation, from the web}

Bruckman, A. (1997). MOOSE Crossing: Construction, community, and learning in a networked virtual world for kids (Doctoral dissertation, Massachusetts Institute of Technology). Retrieved from http:/www-static. cc.gatech.edu/--asb/thesis/

in text citation: (Bruckman, 1997)

\section{Journal article with No DOI}

Bourkhis, K., and Nabi, M. S. (2013). Islamic and conventional banks' soundness during the 2007-2008 financial crisis. Journal Metrics, 22(2), 68-77.

in-text citation: (Bourkhis \& Nabi, 2013).

\section{Journal article with DOI}

Ichwan, M. (2012). The Local Politics Of Orthodoxy: The Majelis Ulama Indonesia in the Post-New Order Banten. Journal Of Indonesian Islam, 6(1), 166-194. doi:http://dx.doi.org/10.15642/JIIS.2012.6.1.166-194

In text citation : (Ichwan, 2012)

\section{Abstract as citation}

Hasan, N. (2012). Islamist Party, Electoral Politics And Da'wah Mobilization Among Youth : The Prosperous Justice Party (PKS) in Indonesia. Journal of Indonesian Islam, 6(1), 17-47. Abstract from http:// jiis.uinsby.ac.id/index.php/jiis/article/view/97

in text citation : (Hasan, 2012)

\section{Mass media article}

Sahal, Akhmad (2014, March 2). Kiai Sahal dan Realisme Fikih.Tempo Magazine, p. 120.

in text citation : (Sahal, 2014) 


\section{Research report}

Fisher, B. S., Cullen, F. T., \& Turner, M. G. (2000). The Sexual Victimization of College Women. Research Report.

in text citation : (Fisher, Cullen, Turner, 2000)

\section{Monograph}

Routray, Bibhu Prasad (2013), National Security Decision-Making in India (RSIS Monograph No. 27). Singapura: Rajaratnam School of International Studies.

in text citation : (Routray, 2013)

\section{Proceeding article}

Sudibyakto, Hizbaron, D.R., \& Jati, R (Ed.) (2009), Proceeding International Seminar Disaster Theory, Research and Policy. International seminar held by Sekolah Pascasarjana, Universitas Gajahmada, Yogyakarta, 8-9 Desember 2009.

in text citation : (sudibyakto and Jati, 2009)

\section{Paper conference/seminar/symposium}

Janutama, Herman Sinung (2011). "Kraton dan Hubungan Antar Agama." Paper presented in Seminar Kraton dan Panatagama held by Center for the Study of Islam and Social Transformation (CISForm), Yogyakarta, 17 November.

in text citation :(Janutama, 2011)

\section{Online article in web}

Shiva, (2006, February). Bioethics: A Third World Issue. Native-web. Diperoleh dari http://www.nativeweb.org/ pages/legal/shiva.html

in text citation : (Shiva, 2006) 


\section{Online research report}

Kessy, S. S. A., \& Urio, F M. (2006). The contribution of microfinance institutions to poverty reduction in Tanzania (Research Report No. 06.3). Retrieved from Research on Poverty Alleviation website: http://www. repoa.or.tz /documents_storage/Publications/Reports/06.3_Kessy_and_ Urio.pcif

in text citation : (kessy and urion, 2006)

\section{Holy book}

Qur an, $2(25)$

In text citation : (Q. al-Baqarah 2:25).

\section{Encyclopaedia}

Graycar, Adam (1992). Social Welfare Policy. Dalam Mary Hawkesworth dan Maurice Kogan (Ed.), Encyclopedia of Government and Politics (Vol. 1). London: Routledge.

in text citation : (Graycar, 1992)

\section{Interview}

Sultan Hamengkubuwono X (interview, 2011, April 19)

in text citation: (Hamengkubuwono, 2011)

\section{Documentary film}

Steijlen, Fridus (2008). A Day in the Life of Indonesia [documentary film, 58 minutes]. Leiden: KITLV Press.

in text citation : (Steijlen, 2008) 
Vol. 3 No. 1, January - April 2018 